\title{
The antihyperlipidemic effect of alginate- free residue from sea tangle in hyperlipidemic rats
}

\author{
Mi-Jin Yim', Jeong Min Lee ${ }^{1}$, Grace Choi ${ }^{1}$, Soon-Yeong $\mathrm{Cho}^{2}$ and Dae-Sung Lee ${ }^{1 *}$ (D)
}

\begin{abstract}
Background: In order to assess the high value-added use of the alginate-free residue of sea tangle, an animal study was performed to evaluate the functional activities and key compounds present. In the animal study, sea tangle and the alginate-free residue demonstrated good anti-hyperlipidemic and anti-arteriosclerotic abilities.

Results: The functional compounds in the alginate-free residue of the sea tangle were effectively extracted by supercritical fluid extraction (SFE). The optimum extraction temperature and pressure were $40{ }^{\circ} \mathrm{C}$ and 6500 psi (M1) in the SFE, a better method in comparison to the conditions of $70{ }^{\circ} \mathrm{C}$ and $4500 \mathrm{psi}(\mathrm{M} 2)$, respectively. The antiatherosclerotic effects of the alginate-free residue of sea tangle (M1, M2) were investigated in Sprague-Dawley rats treated with poloxamer 407, Triton WR 1339, corn oil, and a high-fat diet. The M1 fraction reduced the serum lipid levels with greater efficacy than the $M 2$ fraction. In the hyperlipidemic rats, treatment with $M 1$ decreased the serum triglyceride (TG), total cholesterol (TC), and low-density lipoprotein-cholesterol (LDL-C) levels when compared to the levels in normal rats.
\end{abstract}

Conclusion: Our results demonstrated that the alginate-free residue of sea tangle reduces serum TC, TG, and LDLC. These results suggest that the alginate-free residue of sea tangle contains physiologically active components, such as fucosterol, that may exert beneficial effects in the prevention of atherosclerosis.

Keywords: Antihyperlipidemic, Fucosterol, Saccharina japonica, Sea tangle

\section{Background}

A number of seaweed species are consumed as food in several countries and documented as drugs in traditional Chinese medicine. Fucoidan extracted from L. japonica is an antioxidant, with the fatty acid composition of $n-3$ fatty acids, polysaccharides, vitamins, minerals and trace elements (Jeong et al., 1993), and minor compounds such as sterols. Saccharina japonica is also well known for several biological activities, including antioxidant, anti-mutagenic, and antibacterial activities (Okai et al., 1993; Wang et al., 2006; Park et al., 2009).

Recently, many studies have reported on prospective natural resources regulating the serum cholesterol and triglyceride (TG) levels (Ghule et al., 2006; Lemhadri et al., 2006). Hypercholesterolemia and hyperlipidemia are important risk

\footnotetext{
* Correspondence: daesung@mabik.re.kr

${ }^{1}$ National Marine Biodiversity Institute of Korea (MABIK), Seocheon,

Chungcheongnam-do 325-902, Republic of Korea

Full list of author information is available at the end of the article
}

factors in the initiation and progression of atherosclerotic disease (Goldstein et al., 1973; Harrison et al., 2003). Hypercholesterolemia is characterized by an increase in serum lipids such as TC, low-density lipoprotein cholesterol (LDLC), and TG (Levine et al., 1995). Hyperlipidemia mainly demonstrates increased levels of total cholesterol (TC), TG, and LDL-C, along with a decrease in the high-density lipoprotein-cholesterol (HDL-C). Studies have indicated the potential of synthetic and natural sources that could regulate plasma TC and TG levels in coronary atherosclerosis (Ghule et al., 2009).

The sea tangle is often used as a functional food or alginate extraction material in Korea and Japan. The alginate-free residue of sea tangle is discarded as waste. For the purpose of high value-added use of the alginatefree residue of sea tangle, we investigated the antihyperlipidemic and anti-atherosclerotic effects of the alginate-free residue from sea tangle.

(c) The Author(s). 2019 Open Access This article is distributed under the terms of the Creative Commons Attribution 4.0 International License (http://creativecommons.org/licenses/by/4.0/), which permits unrestricted use, distribution, and reproduction in any medium, provided you give appropriate credit to the original author(s) and the source, provide a link to the Creative Commons license, and indicate if changes were made. The Creative Commons Public Domain Dedication waiver (http://creativecommons.org/publicdomain/zero/1.0/) applies to the data made available in this article, unless otherwise stated. 


\section{Methods}

\section{Materials and chemicals}

The sea tangle (Saccharina japonica) was obtained from a local supplier (Gangneung, Gangwon-do, Korea) in March 2007. Poloxamer-407 (Pluronic F-127) and corn oil were purchased from Sigma (St. Louis, MO, USA). TC (Cholestezyme-V), TG (Triglyzyme-V), and high-density lipoproteincholesterol (HDL-C; HDL-C555) were assayed using commercially available kits (Asan Pharm. Co., Ltd., Korea).

\section{Preparation of samples}

The functional compounds (M1 and M2) in the alginatefree residue of sea tangle were effectively extracted by supercritical fluid extraction (SFX 3560, Lincoln, USA). Supercritical $\mathrm{CO}_{2}$ was used as a solvent and extraction was performed using $1.0 \mathrm{~g}$ sea tangle in a $10-\mathrm{mL}$ extractor. The extraction was performed for 20 min with a fluid flow rate of $1.0 \mathrm{~mL} / \mathrm{min}$, measured at the pump head. The extraction was performed at $40{ }^{\circ} \mathrm{C}$ and 6500 psi in the sample cartridge for $10 \mathrm{~min}$, followed by extraction through the cartridge at $70{ }^{\circ} \mathrm{C}$. The extracted sample was collected in collection vial with ethanol.

\section{Animals and treatments}

Sprague-Dawley male rats weighing 130-150 g were obtained from the Dae-han Biolink Co., Ltd. (Chungbuk, Republic of Korea), maintained under constant conditions (temperature $20 \pm 2{ }^{\circ} \mathrm{C}$, humidity 40-60\%, light $12-\mathrm{h}$ cycle) and acclimatized for 1 week. The rats had free access to drinking water, with the feed prepared according to the recommendations of the American Institute of $\mathrm{Nu}$ trition (AIN-76). After the animals were fed the AIN-76 diets, 50 or $100 \mathrm{mg}$ (lipid solution/ $\mathrm{kg}$ of body weight in $5 \%$ Tween 80 ) of the alginate-free residue extracted from sea tangle powder was orally administered, once a day for 2 weeks. Following this period, the rats were fasted for 24 $\mathrm{h}$ and killed and dissected under $\mathrm{CO}_{2}$ anesthesia. All animal experiments were approved by the University of Kyungsung Animal Care and Use Committee.

\section{Experimental procedures}

The poloxamer-407 hyperlipidemic diet model was determined according to the method described by Wout et al. (1992). The rats were administered a $300 \mathrm{mg} / \mathrm{kg}$ dose of poloxamer 407 intraperitoneally, prepared by combining the agent with saline solution.

The Triton WR-1339 hyperlipidemic diet model was performed according to the method described by Kusama et al. (1998). Triton WR-1339 (200 mg/kg) was injected into the tail vein after a fasting period of $16 \mathrm{~h}$. After inducing hyperlipidemia, the animals were anesthetized with the $\mathrm{CO}_{2}$ gas and blood was gathered for analysis $18 \mathrm{~h}$ later.

According to Duhault et al. (1976), we administered corn oil in the diet at $3 \mathrm{~g} / \mathrm{kg}$. The compositions of the normal and high-fat diet are shown in Table 1 . The high-fat-diet-treated rats were orally administered the test substance for the last week, with the high-fat diets fed daily for 6 weeks.

\section{Extraction of feces lipids}

Based on the method of Folch et al. (1957), the lipids were extracted by homogenization of the feces with 2:1 chloroform-methanol $(\mathrm{v} / \mathrm{v})$, followed by centrifugation. The lipids were extracted based on the dry weight of the feces and assayed for TC and TG concentration using a standard enzymatic assay kit (Asan Pharm., Korea).

\section{Glucose analysis}

The levels of TG, TC, and HDL-C were determined by enzymatic colorimetric methods using commercial kits (Shinyang Chemical Co., Busan, Korea). The concentration of LDL-C was calculated using the following equation (Friedwald et al., 1972).

LDL-C = TC-HDL-C-(TG/5)

\section{Identification of M1 with HPLC}

High-performance liquid chromatograph (HPLC, Hitachi, Tokyo, Japan) system was performed using a Lichrospher RP-18e column $(8 \times 250 \mathrm{~mm}$, Merck). The mobile phase used was methanol/acetonitrile $(7: 3, v / v)$ at a flow rate of $1.0 \mathrm{~mL} / \mathrm{min}$, and detection was performed at $450 \mathrm{~nm}$ and $210 \mathrm{~nm}$ by a diode array detector (L7455 type, Hitachi). The amounts of M1 fractions were quantified from their peak area by the use of a standard curve identified with fucosterol.

\section{Statistical analysis}

All results are presented as the mean \pm SD. Data were evaluated by one-way ANOVA using SPSS (IBM SPSS,

Table 1 Composition of the normal and high-fat diet (Unit: $\mathrm{g} / 100 \mathrm{~g})$

\begin{tabular}{lll}
\hline Ingredients & Normal diet & High-fat diet \\
\hline Casein & 20 & 29 \\
Corn starch & 60 & 10 \\
Sugar & 0.0 & 10 \\
Lard & 0.0 & 35 \\
Corn oil & 9.0 & 5.0 \\
Cellulose & 5.0 & 5.0 \\
AlN76 mineral mixture & 3.5 & 3.5 \\
AlN76 vitamin mixture & 1.0 & 1.0 \\
Cholesterol & 1.0 & 1.0 \\
DL-methionine & 0.3 & 0.3 \\
Choline & 0.2 & 0.2 \\
\hline
\end{tabular}

AIN76 mixture: Nutritional Biochemicals, ICN Life Science Group, Cleveland, Ohio 
Table 2 Effect of M1and M2 on the serum lipid levels in poloxamer-407 injected rats

\begin{tabular}{llll}
\hline Treatment & $\begin{array}{l}\text { Dose } \\
\mathrm{mg} / \mathrm{kg}\end{array}$ & $\begin{array}{l}\text { Triglyceride } \\
\mathrm{mg} / \mathrm{dL}\end{array}$ & Total cholesterol \\
\hline Normal & & $80.6 \pm 8.46^{\mathrm{d}}$ & $66.5 \pm 9.49^{\mathrm{c}}$ \\
Poloxamer-407 & & $1101.6 \pm 63.7^{\mathrm{a}}$ & $770.3 \pm 48.8^{\mathrm{a}}$ \\
M1 & 100 & $881.3 \pm 52.2^{\mathrm{c}}$ & $620.9 \pm 33.6^{\mathrm{b}}$ \\
M2 & 100 & $996.5 \pm 70.3^{\mathrm{b}}$ & $728.6 \pm 43.1^{\mathrm{a}}$ \\
\hline
\end{tabular}

Values represent mean \pm S.D. $(n=8)$. Values sharing the same column superscript letter are not significantly different from each other $(P<0.05)$ by Duncan's multiple range test

Armonk, NY, USA), after which the differences between the means values were assessed using Duncan's multiple range test. Results were considered statistically significant at $P<0.05$.

\section{Results}

\section{The effect of M1 and M2 on poloxamer 407-induced} hyperlipidemia

We assessed the effect of the oral administration of M1 and M2 $100 \mathrm{mg} / \mathrm{kg}$ of body weight, once a day for 2 weeks, on the serum lipid levels in poloxamer 407induced hyperlipidemic rats. Serum TG and TC levels were reduced by $\mathrm{M} 1$ and $\mathrm{M} 2$ when compared to the control rats, in poloxamer 407-induced hyperlipidemic rats (Table 2). M1 demonstrated a more potent effect on the serum lipid levels than the M2 fraction. Hence, we proceeded to assess if M1 possessed a dose-dependent effect. The administration of the M1 at a dose of 50 and $100 \mathrm{mg} / \mathrm{kg}$ body weight significantly reduced serum lipid levels when compared to the control rats (Table 3 ).

\section{The effect of M1 on Triton WR 1339-induced hyperlipidemia}

Rats with hyperlipidemia induced by Triton WR 1339 demonstrated remarkably high serum levels of TG, TC, and LDL-C. However, the administration of the M1 at doses of 50 and $100 \mathrm{mg} / \mathrm{kg}$ body weight significantly reduced the TG levels in the hyperlipidemic rats as compared to the control rats (Table 4). The TC and LDL-C

Table 3 Effect of M1 on the serum lipid levels in poloxamer407 treated rats

\begin{tabular}{llll}
\hline Treatment & $\begin{array}{l}\text { Dose } \\
\mathrm{mg} / \mathrm{kg}\end{array}$ & $\begin{array}{l}\text { Triglyceride } \\
\mathrm{mg} / \mathrm{dL}\end{array}$ & Total cholesterol \\
\hline Normal & & $81.7 \pm 9.53^{\mathrm{d}}$ & $69.8 \pm 8.56^{\mathrm{c}}$ \\
Poloxamer-407 & & $1207.8 \pm 100.5^{\mathrm{a}}$ & $800.6 \pm 50.4^{\mathrm{a}}$ \\
M1 & 50 & $937.5 \pm 87.9^{\mathrm{b}}$ & $740.6 \pm 47.8^{\mathrm{a}}$ \\
& 100 & $741.6 \pm 94.7^{\mathrm{c}}$ & $531.2 \pm 63.2^{\mathrm{a}}$ \\
\hline
\end{tabular}

Values represent mean \pm S.D. $(n=9)$. Values sharing the same column superscript letter are not significantly different from each other $(P<0.05)$ by Duncan's multiple range test
Table 4 Effect of M1 on the serum triglyceride, total cholesterol and low-density lipoprotein-cholesterol (LDL-C) levels in Triton WR 1339-induced hyperlipidemic rats

\begin{tabular}{lllll}
\hline Treatment & $\begin{array}{l}\text { Dose } \\
\mathrm{mg} / \mathrm{kg}\end{array}$ & $\begin{array}{l}\text { Triglyceride } \\
\mathrm{mg} / \mathrm{dL}\end{array}$ & Total cholesterol & LDL-C \\
\hline Normal & & $98.4 \pm 15.9^{\mathrm{d}}$ & $79.6 \pm 9.36^{\mathrm{c}}$ & $18.2 \pm 2.43^{\mathrm{c}}$ \\
Control & & $736.5 \pm 308^{\mathrm{a}}$ & $191.4 \pm 14.5^{\mathrm{a}}$ & $67.3 \pm 8.57^{\mathrm{a}}$ \\
M1 & 50 & $639.5 \pm 45.7^{\mathrm{b}}$ & $167.0 \pm 10.8^{\mathrm{b}}$ & $53.7 \pm 4.53^{\mathrm{b}}$ \\
& 100 & $424.8 \pm 38.5^{\mathrm{c}}$ & $150.9 \pm 7.53^{\mathrm{b}}$ & $49.0 \pm 5.07^{\mathrm{b}}$
\end{tabular}

Values represent mean \pm S.D. $(n=9)$. Values sharing the same column superscript letter are not significantly different from each other $(P<0.05)$ by Duncan's multiple range test

were reduced in the M1-treated groups compared with control rats; however, no dose-dependent differences were observed between M1 and M2.

The effect of $\mathrm{M} 1$ on $30 \%$ corn oil-induced hyperlipidemia Table 5 shows the serum lipid levels following the oral administration of M1 50 and $100 \mathrm{mg} / \mathrm{kg}$ body weight. The serum lipid levels such as TG and TC were remarkably increased in the control rats induced corn oil; however, the administration of M1 significantly reduced the serum TG and TC levels.

\section{The effect of M1 on high fat diet-induced hyperlipidemia}

The effects of M1 on the serum lipid levels of rats fed a high-fat diet are shown in Table 6. The rats fed a highfat diet reported significantly increased levels of serum of TG, TC, and LDL-C compared to the normal rats. The serum lipid levels including TG, TC, and LDL-C were significantly reduced by M1 $100 \mathrm{mg} / \mathrm{kg}$, with no reduction observed in the serum lipid levels of the control rats (Table 6). The abdominal fat pad weights in the normal and diet-induced obesity rats fed with M1 were also assessed. The weights of the retroperitoneal WAT, epididymal WAT, and total abdominal WAT per body weight of rats were significantly lower in the dietinduced obesity rats treated with M1 $100 \mathrm{mg} / \mathrm{kg}$ body weight than the control rats (Table 7). The fecal contents of the diet-induced obesity rats were not altered when compared to dose-dependent of M1. The rats fed

Table 5 Effect of M1 on the serum triglyceride and total cholesterol levels in 30\% corn oil-induced hyperlipidemic rats

\begin{tabular}{llll}
\hline Treatment & $\begin{array}{l}\text { Dose } \\
\mathrm{mg} / \mathrm{kg}\end{array}$ & $\begin{array}{l}\text { Triglyceride } \\
\mathrm{mg} / \mathrm{dL}\end{array}$ & Total cholesterol \\
\hline Normal & & $86.8 \pm 10.5^{\mathrm{c}}$ & $73.5 \pm 8.56^{\mathrm{c}}$ \\
Control & & $230.7 \pm 19.7^{\mathrm{a}}$ & $98.8 \pm 7.79^{\mathrm{a}}$ \\
M1 & 50 & $197.6 \pm 20.3^{\mathrm{b}}$ & $91.6 \pm 9.66^{\mathrm{a}}$ \\
& 100 & $172.9 \pm 11.1^{\mathrm{b}}$ & $86.7 \pm 5.24^{\mathrm{b}}$ \\
\hline
\end{tabular}

Values represent mean \pm S.D. $(n=9)$. Values sharing the same column superscript letter are not significantly different from each other $(P<0.05)$ by Duncan's multiple range test 
Table 6 Serum lipid contents of the normal and diet-induced obesity rats fed with $\mathrm{M} 1$ for 2 weeks

\begin{tabular}{lllll}
\hline Treatment & $\begin{array}{l}\text { Dose } \\
\mathrm{mg} / \mathrm{kg}\end{array}$ & $\begin{array}{l}\text { Triglyceride } \\
\mathrm{mg} / \mathrm{dL}\end{array}$ & Total cholesterol & LDL-C \\
\hline Normal & & $76.9 \pm 4.80^{\mathrm{c}}$ & $66.9 \pm 4.57^{\mathrm{c}}$ & $20.6 \pm 4.26^{\mathrm{c}}$ \\
Control & & $121.3 \pm 11.3^{\mathrm{a}}$ & $119.0 \pm 3.56^{\mathrm{a}}$ & $76.5 \pm 10.5^{\mathrm{a}}$ \\
M1 & 50 & $111.6 \pm 9.53^{\mathrm{a}, \mathrm{b}}$ & $115.2 \pm 5.27^{\mathrm{a}}$ & $65.2 \pm 5.28^{\mathrm{a}}$ \\
& 100 & $97.7 \pm 5.23^{\mathrm{b}}$ & $106.3 \pm 3.11^{\mathrm{b}}$ & $51.4 \pm 3.26^{\mathrm{b}}$ \\
\hline
\end{tabular}

Values represent mean \pm S.D. $(n=9)$. Values sharing the same column superscript letter are not significantly different from each other $(P<0.05)$ by Duncan's multiple range test

the M1 $100 \mathrm{mg} / \mathrm{kg}$ of body weight diet decreased of total lipid, TG and TC (Table 8). The rats fed M1 $100 \mathrm{mg} / \mathrm{kg}$ reported lower blood leptin and insulin levels than the control rats (Table 9).

\section{Identification of compounds}

To find a key functional anti-hyperlipidemic compound in $\mathrm{M} 1$, the properties were compared with the reference substance after separation using the HPLC (data not shown). The results demonstrated fucosterol as the key functional compound (Fig. 1).

\section{Discussion}

Hyperlipidemia, obesity, and diabetes mellitus are chronic diseases associated with serious complications that may consequently increase the risk of atherosclerosis. Thus, regulating the serum cholesterol levels is important, as increased serum levels of TC and LDL-C are the significant determinants in the development of atherosclerosis (Jeong et al., 2010).

In the present study, we investigated the effects of the alginate residue extracted from sea tangle on the serum lipid profile of hyperlipidemic and diet-induced obesity rats. The results demonstrated that M1 administration in the hyperlipidemic rats significantly decreased the serum TC, TG, and LDL-C levels. Previous studies have reported the hypolipidemic effects of edible seaweeds, dietary fiber, plant sterols, and herbal extracts, as indicated by decreased serum TC, TG, and LDL-C levels on

Table 7 Abdominal fat pad weights in the normal and dietinduced obesity rats fed with M1 for 2 weeks

\begin{tabular}{|c|c|c|c|c|}
\hline Treatment & $\begin{array}{l}\text { Dose } \\
\mathrm{mg} / \mathrm{kg}\end{array}$ & $\begin{array}{l}\text { Retroperitoneal } \\
\text { g }\end{array}$ & Epididymal & Total abdominal \\
\hline Normal & & $6.44 \pm 0.37^{c}$ & $7.82 \pm 0.46^{c}$ & $14.26 \pm 0.97^{c}$ \\
\hline Control & & $10.58 \pm 0.83^{a}$ & $12.06 \pm 0.53^{a}$ & $22.56 \pm 1.54^{a}$ \\
\hline \multirow[t]{2}{*}{ M1 } & 50 & $9.53 \pm 0.46^{a, b}$ & $11.17 \pm 0.50^{a, b}$ & $20.70 \pm 0.86^{a, b}$ \\
\hline & 100 & $8.69 \pm 0.50^{b}$ & $10.53 \pm 0.49^{b}$ & $19.22 \pm 0.95^{b}$ \\
\hline
\end{tabular}

Values represent mean \pm S.D. $(n=9)$. Values sharing the same column superscript letter are not significantly different from each other $(P<0.05)$ by Duncan's multiple range test
Table 8 Feces lipid contents of the normal and diet-induced obesity rats fed with $\mathrm{M} 1$ for 2 weeks

\begin{tabular}{llllll}
\hline Treatment & $\begin{array}{l}\text { Dose } \\
\text { mg/ } \\
\text { kg }\end{array}$ & $\begin{array}{l}\text { Dry } \\
\text { weight } \\
\mathrm{g} / \text { day }\end{array}$ & Total lipid & $\begin{array}{l}\text { Triglyceride } \\
\mathrm{mg} / \mathrm{g}\end{array}$ & $\begin{array}{l}\text { Total } \\
\text { cholesterol }\end{array}$ \\
\hline Normal & & $2.46 \pm$ & $66.4 \pm$ & $16.4 \pm$ & $3.9 \pm 0.79^{\mathrm{c}}$ \\
& & $0.17^{\mathrm{a}}$ & $6.83^{\mathrm{c}}$ & $1.36^{\mathrm{c}}$ & \\
Control & & $1.01 \pm$ & $133.2 \pm$ & $17.8 \pm$ & $15.6 \pm 2.37^{\mathrm{b}}$ \\
& & $0.11^{\mathrm{b}}$ & $5.87^{\mathrm{b}}$ & $1.58^{\mathrm{c}}$ & \\
M1 & 50 & $0.93 \pm$ & $140.5 \pm$ & $21.3 \pm$ & $18.6 \pm 2.46^{\mathrm{a}, \mathrm{b}}$ \\
& & $0.15^{\mathrm{b}}$ & $7.66^{\mathrm{b}}$ & $2.17^{\mathrm{b}}$ & \\
& 100 & $0.85 \pm$ & $153.9 \pm$ & $26.8 \pm$ & $20.5 \pm 1.47^{\mathrm{a}}$ \\
& & $0.13^{\mathrm{b}}$ & $6.05^{\mathrm{a}}$ & $1.90^{\mathrm{a}}$ & \\
& & &
\end{tabular}

Values represent mean \pm S.D. $(n=9)$. Values sharing the same column superscript letter are not significantly different from each other $(P<0.05)$ by Duncan's multiple range test

rats (Nigon et al., 2001; Ara et al., 2002; Yamada et al., 2003; Megalli et al., 2005; Jeong et al., 2010). According to these studies, lowering serum TC and LDL-C levels plays an important role in reducing the risk of developing atherosclerosis.

In addition, the diet-induced obesity rats treated with M1 reported decreased abdominal fat weight compared to the control rats. These results suggest that the M1 fraction effects obesity by reducing the abdominal fat weight in obese rats. We also investigated the total lipid, TG, and TC levels in the fecal contents of the control and dietinduced obesity rats fed with M1. The M1-treated rats reported increased fecal content of the total lipid, TG, and TC levels. This data indicated that M1 lowered the serum lipid through the increased excretion of total lipid, TG, and TC from the body. Hence, it was concluded that M1 demonstrated hypolipidemic activity in rats. Moreover, lowering the serum cholesterol level is crucial for the prevention of cardiovascular diseases (Hideomi et al., 2005). M1 treatments also exerted anti-hyperlipidemic effects by regulating the serum lipid levels in rats with induced hyperlipidemia. HPLC was performed to confirm the presence of functional components in the M1 fraction, and the identification of fucosterol in the M1 fraction was confirmed by the comparison of retention times with the

Table 9 Serum leptin and insulin levels in the normal and dietinduced obesity rats fed with M1 for 2 weeks

\begin{tabular}{llll}
\hline Treatment & $\begin{array}{l}\text { Dose } \\
\mathrm{mg} / \mathrm{kg}\end{array}$ & $\begin{array}{l}\text { Leptin } \\
\mathrm{mg} / \mathrm{dL}\end{array}$ & Insulin \\
\hline Normal & & $8.76 \pm 0.47^{\mathrm{c}}$ & $3.56 \pm 0.19^{\mathrm{b}}$ \\
Control & & $26.25 \pm 6.43^{\mathrm{a}}$ & $4.16 \pm 0.30^{\mathrm{a}}$ \\
M1 & 50 & $24.83 \pm 3.29^{\mathrm{a}}$ & $4.06 \pm 0.28^{\mathrm{a}}$ \\
& 100 & $16.55 \pm 3.10^{\mathrm{b}}$ & $3.97 \pm 0.21^{\mathrm{a}, \mathrm{b}}$ \\
\hline
\end{tabular}

Values represent mean \pm S.D. $(n=9)$. Values sharing the same column superscript letter are not significantly different from each other $(P<0.05)$ by Duncan's multiple range test 


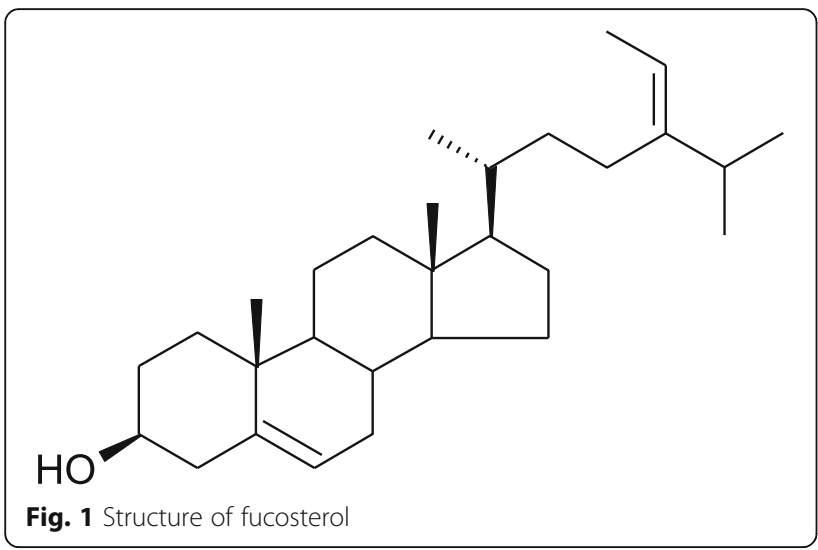

reference standard. In previous studies, fucosterol, isolated from marine algae Pelvetia siliquosa, has been investigated for anti-oxidant and anti-diabetic activities (Lee et al., 2003; Lee et al., 2004). Furthermore, many studies have reported that among the serum lipids, LDL-C is the most dangerous, as the oxidation of LDL leads to its increased infiltration in the arterial walls (Aviram, 1993). Therefore, reducing the oxidation of $\mathrm{LDL}-\mathrm{C}$ is essential due to the presumed involvement in the development of atherosclerotic disease.

\section{Conclusions}

Our results demonstrated that the alginate-free residue of sea tangle reduces serum levels of TC, TG, and LDLC. These results suggest that the alginate-free residue of sea tangle contains physiologically active components, such as fucosterol, that may exert beneficial effects in the prevention of atherosclerosis.

\section{Abbreviations}

HDL-C: High-density lipoprotein-cholesterol; LDL-C: Low-density lipoproteincholesterol; SFE: Supercritical fluid extraction; TC: Total cholesterol; TG: Triglycerides; TSO: Trans-stilbene oxide

\section{Acknowledgements}

This work was supported by the study for the establishment of the marine natural products library, funded by the National Marine Biodiversity Institute of Korea (2019M00700).

\section{Authors' contributions}

MJY carried out the hypolipidemic activity and drafted the manuscript. GC carried out the glucose and cholesterol analysis. JML identified fucosterol as the key functional compound. SYC participated in the design of the study and helped to draft the manuscript. DSL designed the study and completed the manuscript. All authors read and approved the final manuscript.

\section{Funding}

This work was supported by the study for the establishment of the marine natural products library, funded by the National Marine Biodiversity Institute of Korea (2019M00700).

Availability of data and materials Not applicable.

\section{Ethics approval and consent to participate}

Animal experiments were performed according to the institutional guidelines for the care and the use of laboratory animals, and the protocol was approved by the Animal Ethics Committee of Kyungsung University.

\section{Consent for publication}

Not applicable.

\section{Competing interests}

The authors declare that they have no competing interests.

\section{Author details}

${ }^{1}$ National Marine Biodiversity Institute of Korea (MABIK), Seocheon, Chungcheongnam-do 325-902, Republic of Korea. ${ }^{2}$ Department of Food Processing and Distribution, Gangneung-Wonju National University, 210-702, Gangneung 25457, Republic of Korea.

Received: 27 September 2019 Accepted: 12 November 2019 Published online: 27 November 2019

\section{References}

Ara J, Sultana V, Qasim R, Ahmad VU. Hypolipidemic activity of seaweed from Karachi Coast. Phytother Res. 2002:16:479-83.

Aviram M. Modified forms of low density lipoprotein and atherosclerosis. Atherosclerosis. 1993:98:1-9.

Duhault J, Boulanger M, Beregi L, Sicot N, Bouvier F. A new type of hyperlipidemic agent comparative assay in rats. Atherosclerosis. 1976;23:63-72.

Folch J, Lees M, Sloane Stanley GH. A simple method for the isolation and purification of total lipids from animal tissues. J Biol Chem. 1957;226:497-509.

Friedwald WT, Levy RL, Fedreicson DS. Estimation of the concentration of lowdensity lipoprotein cholesterol in plasma, without was of the preparative ultracentrifuge. Clin Chem. 1972;18:499-506.

Ghule BV, Ghante MH, Saoji AN, Yeole PG. Hypolipidemic and antihyperlipidemic effects of Lagenaria siceraria Stand. Fruit extracts. Indian J Exp Biol. 2006;44:905-9.

Ghule BV, Ghante MH, Saoji AN, Yeole PG. Antihyperlipidemic effect of the methanolic extract from Lagenaria siceraria Stand. Fruit in hyperlipidemic rats. J Ethnopharmacol. 2009;124:333-7.

Goldstein JL, Schroot HG, Hazzard WR, Bierman EL, Motulsky AG. Hyperlipidemia in coronary heart disease 11: genetic analysis of lipid levels in 176 families and delineation of a new inherited disorder, combined hyperlipidemia. J Clin Invest. 1973:52:1544-68.

Harrison D, Griendling KK, Landmesser U, Hornig B, Drexler H. Role of oxidative stress in atherosclerosis. Am J Cardiol. 2003;91:7A-11A.

Hideomi A, Makoto K, Daniel AC, Haruka O, Takaaki H. Effect of a seaweed mixture on serum lipid level and platelet aggregation in rats. Fish Sci. 2005 71:1160-6.

Jeong BY, Cho DM, Moon SK, Pyeun JH. Quality factors and functional components in the edible seaweeds - I. Distribution on n-3 fatty acids in 10 species of seaweeds by their habitats. J Korean Soc Food Sci Nutr. 1993;22: $612-28$.

Jeong SC, Jeong YT, Yang BK, Islam R, Koyyalamudi SR, Pang G, Cho KY, Song CH. White button mushroom (Agaricus bisporus) lowers blood glucose and cholesterol levels in diabetic and hypercholesterolemic rats. Nutr Res. 2010; 30:49-56.

Kusama H, Nishiyama M, Ikeda S. Pharmacological investigation of bezafibrate a hypolopodemic agent. Effects of bezafibrate on normal and experimental hyperlipidemia in rats. Nihon Yakurigaku Zasshi. 1998:92:175-80.

Lee S, Lee YS, Jung SH, Kang SS, Shin KH. Anti-oxidant activities of fucosterol from the marine algae Pelvetia siliquosa. Arch Pharm Res. 2003;26:719-22.

Lee YS, Shin KH, Kim BK, Lee S. Anti-diabetic activities of fucosterol from Pelvetia siliquosa. Arch Pharm Res. 2004;27:1120-2.

Lemhadri A, Hajji L, Michel JB, Eddouks MJ. Cholesterol and triglycerides lowering activities of caraway fruits in normal and streptozotocin diabetic rats. J Ethnopharmacol. 2006;106:321-6.

Levine GN, Keaney JF Jr, Vita JA. Cholesterol reduction in cardiovascular disease. Clinical benefits and possible mechanisms. N Engl J Med. 1995;332:512-21.

Megalli S, Aktan F, Davies NM, Roufogalis BD. Phytopreventative antihyperlipidemic effects of Gynostemma pentaphyllum in rats. J Pharm Pharm Sci. 2005:8:507-15. 
Nigon F, Serfaty-Lacrosniere C, Beucler I, Beucler I, Chauvois D, Neveu C, Giral P, Giral P, Chapman MJ, Bruckert E. Plant sterol-enriched margarine lowers plasma LDL in hyperlipidemic subjects with low cholesterol intake: effect of fibrate treatment. Clin Chem Lab Med. 2001;39:634-40.

Okai Y, Higashi-okai K, Nakamura S. Identification of heterogenous antimutagenic activities in the extract of edible brown seaweeds, Laminaria japonica (Makonbu) and Undaria pinnatifida (Wakame) by the umu gene expression system in Salmonella typhimurium (TA1535/pSK1002). Mutat Res. 1993;30:63-70.

Park PJ, Kim EK, Lee SJ, Park SY, Kang DS, Jung BM, Kim KS, Je HY, Ahn CB. Protective effects against $\mathrm{H}_{2} \mathrm{O}_{2}$-induced damage by enzymatic hydrolysates of an edible brown seaweed, sea tangle (Laminaria japonica). J Med Chem. 2009;12:159-66.

Wang Y, Tang XX, Yang Z, Yu ZM. Effect of alginic acid decomposing bacterium on the growth of Laminaria japonica (Phaephyceae). J Environ Sci. 2006:18:543-51.

Wout ZG, Pec EA, Johnston TP. Biological activity of urease formulated in Poloxamer-407 after intraperitoneal injection in the rat. J Pharm Sci. 1992;81:626-30.

Yamada K, Tokunaga Y, Ikeda A, Ohkura K, Kaku-Ohkura S, Mamiya S, Lim $\mathrm{BO}$, Tachibana $\mathrm{H}$. Effect of dietary fiber on the lipid metabolism and immune function of aged Sprague-Dawley rats. Biosci Biotechnol Biochem. 2003:67:429-33.

\section{Publisher's Note}

Springer Nature remains neutral with regard to jurisdictional claims in published maps and institutional affiliations.

Ready to submit your research? Choose BMC and benefit from:

- fast, convenient online submission

- thorough peer review by experienced researchers in your field

- rapid publication on acceptance

- support for research data, including large and complex data types

- gold Open Access which fosters wider collaboration and increased citations

- maximum visibility for your research: over $100 \mathrm{M}$ website views per year

At BMC, research is always in progress.

Learn more biomedcentral.com/submissions 